\title{
Physico-Chemical Quality of Groundwater in Keta South, Ghana
}

\author{
Norvivor Forgive Awo ${ }^{1}$, Gordon Chris ${ }^{2}$, Appeaning-Addo Kwasi ${ }^{3}$ \\ ${ }^{1}$ Department of Epidemiology and Biostatistics, School of Public Health (Hohoe Campus), University of Health and Allied Sciences, \\ Ho-Volta Region, Ghana \\ ${ }^{2}$ Institute for Environmental and Science Studies, University of Ghana, Accra, Ghana \\ ${ }^{3}$ Department of Marine and Fisheries Science, University of Ghana, Accra, Ghana
}

Email address:

a4woforgive@gmail.com (Norvivor F. A.), kappeaning-addo@ug.edu.gh (Appeaning-Addo K.)

\section{To cite this article:}

Norvivor Forgive Awo, Gordon Chris, Appeaning-Addo Kwasi. Physico-Chemical Quality of Groundwater in Keta South, Ghana. Journal of Health and Environmental Research. Vol. 3, No. 3, 2017, pp. 51-56. doi: 10.11648/j.jher.20170303.12

Received: June 7, 2017; Accepted: August 8, 2017; Published: September 26, 2017

\begin{abstract}
The paper investigated physico-chemical quality of groundwater, considering the relative proximity of hand dug wells to coastal environment, but most importantly close to insanitary facilities like refuse dumps, septic tanks and pit latrines; this was done in selected coastal communities in the Keta. Thirty vials of water samples from selected hand dug wells in two seasons were tested for $\mathrm{pH}$, Total Dissolved Solids (TDS), Conductivity, Turbidity, Calcium, Magnesium, Nitrate, Sulphate, and Phosphate; WHO standards of drinking water were adopted to validate the results obtained and statistical analysis run. Statistical analysis of results showed a statistical significance in Turbidity, Nitrate, Phosphate, Calcium and Magnesium values at $\mathrm{p}<0.05$, between the two seasons. There was a weak but significant correlation between Calcium and distance $(\mathrm{r}=0.398)$ and a strong correlation between Magnesium and distance $(\mathrm{r}=0.763)$. The study revealed that all the hand dug wells sampled recorded relatively high concentration of conductivity, turbidity, TDS, Calcium, Magnesium and Phosphates, irrespective of their proximity to the insanitary facilities and coastal environment, apart from nitrates when compared to WHO standards of drinking water.
\end{abstract}

Keywords: Groundwater, Physico Chemical Quality, Coastal Communities, Sanitation

\section{Introduction}

Water remains a vital resource that supports daily important domestic, agriculture, industrial and physiological activities. However, due to the drying up of many surface waters and pollution arising from increasing human population as well as poor land use practices, attention has drifted to groundwater as an alternative and reliable water source (Aydin, 2006). Groundwater provides potable water to an estimated 1.5 billion people worldwide (DFID, 2001) and has proved to be the most reliable resource for meeting rural water demand in the sub-Saharan Africa. Groundwater is generally considered a "safe source" of drinking water because it is abstracted with low microbial load therefore there would be a little need for treatment before drinking (Palamuleni \& Akoth, 2015). However, groundwater resources are commonly vulnerable to pollution and threaten by human activities which may degrade their quality. Examples of these human activities include poor waste disposal practices, poor protection of well heads, proximal siting of toilet facilities and sewage systems close to groundwater abstraction points and in catchment areas, and the mode of abstraction. According to Graham \& Polizzotto (2013), these human activities make groundwater vulnerable to contamination. Natural conditions such as geology of landcover and flooding caused by storm surges also expose groundwater to contamination. Generally, groundwater quality varies from place to place, sometimes depending on seasonal changes and as groundwater flows through the sediments, metals such as iron and manganese are dissolved and may later be found in high concentrations in the water (Basavaraddi et al., 2012); Moyo, 2013). Climate change 
affect groundwater recharge through changes in precipitation and temperature as well as facilitate saltwater intrusion into groundwater systems in coastal zones. Salinization of groundwater systems can lead to a severe deterioration of the quality of existing fresh groundwater resources and create a reduction in the amount of freshwater resources available in coastal aquifers.

The Keta basin in Ghana, forms one of the five sedimentary basins in the southern part of the country (Banoeng-Yakubu et al., 2006). Underneath the top plain sand is an extensive shallow aquifers. Most of the communities within the Keta basin rely on hand dug wells as a source of water supply for both domestic and agricultural purposes. The major potential drinking water quality problem of domestic water supply in the Keta basin is salinization of groundwater in hand dug wells and in deep boreholes (Helstrup et al., 2007). A lot of prospective sites for wells and boreholes were not completed due to salinity problems in the aquifers in the Keta basin (Yidana et al., 2010). Besides salinization, contamination through insanitary conditions around the wellheads and close proximity of wellheads to toilet facilities, waste disposal sites and sewage systems could also affect groundwater quality in the Keta basin. However, there is little or no evidence of groundwater contamination and sanitation practices in the Keta basin. Hence this study assessed the sanitary conditions around hand-dug wells and the phyisco-chemical properties of the water from the hand-dug wells in three coastal communities in Keta district.

\section{Materials and Methods}

\subsection{Study Area}

Keta municipality is located in the Volta region, which is in the south-eastern part of Ghana (Figure 1.0). It is relatively a low-lying coastal plain with a mean height of 7 meters above sea level; the lowest point is approximately between 13.5 metres below sea level (Yidana et al., 2010). This has exposed the study area to intense seasonal flooding, increased coastal erosion and storm surges. The study area falls between latitude $5^{\circ} .55^{\prime} \mathrm{N}-6^{\circ} .20^{\prime} \mathrm{N}$ and longitudes $0^{\circ} .59^{\prime} \mathrm{N}-1^{\circ} .15 \mathrm{E}$. The Keta basin lies within the dry equatorial climatic region, and it is the driest part of the country. The coastal area has two clearly defined seasons, the Dry season and the Rainy season. The Rainy season exhibits double maxima, the main one occurring between April and June and the minor one between September and October. June is usually the wettest month in the area and this coincides with the major and minor cropping seasons in the study area (Finlayson et al., 2000). Although the district falls within the climate with an annual average rainfall of less than $1,000 \mathrm{~mm}$, the specific average annual rainfall for Atorkor is between $800 \mathrm{~mm}-900 \mathrm{~mm}$, Srogbe has annual rainfall between $900 \mathrm{~mm}-$ $1000 \mathrm{~mm}$ and Whuti also having an annual rainfall between $1000 \mathrm{~mm}-1100 \mathrm{~mm}$. The average annual temperature of the three areas is between $27^{\circ} \mathrm{C}-28^{\circ} \mathrm{C}$. The geology of the three communities is mostly loose unconsolidated soil that allows rapid seepage into hand dug wells.

\section{DISTRIBUTION OF SOME SELECTED HAND DUG WELLS IN THE KETA-SOUTH DISTRICT}

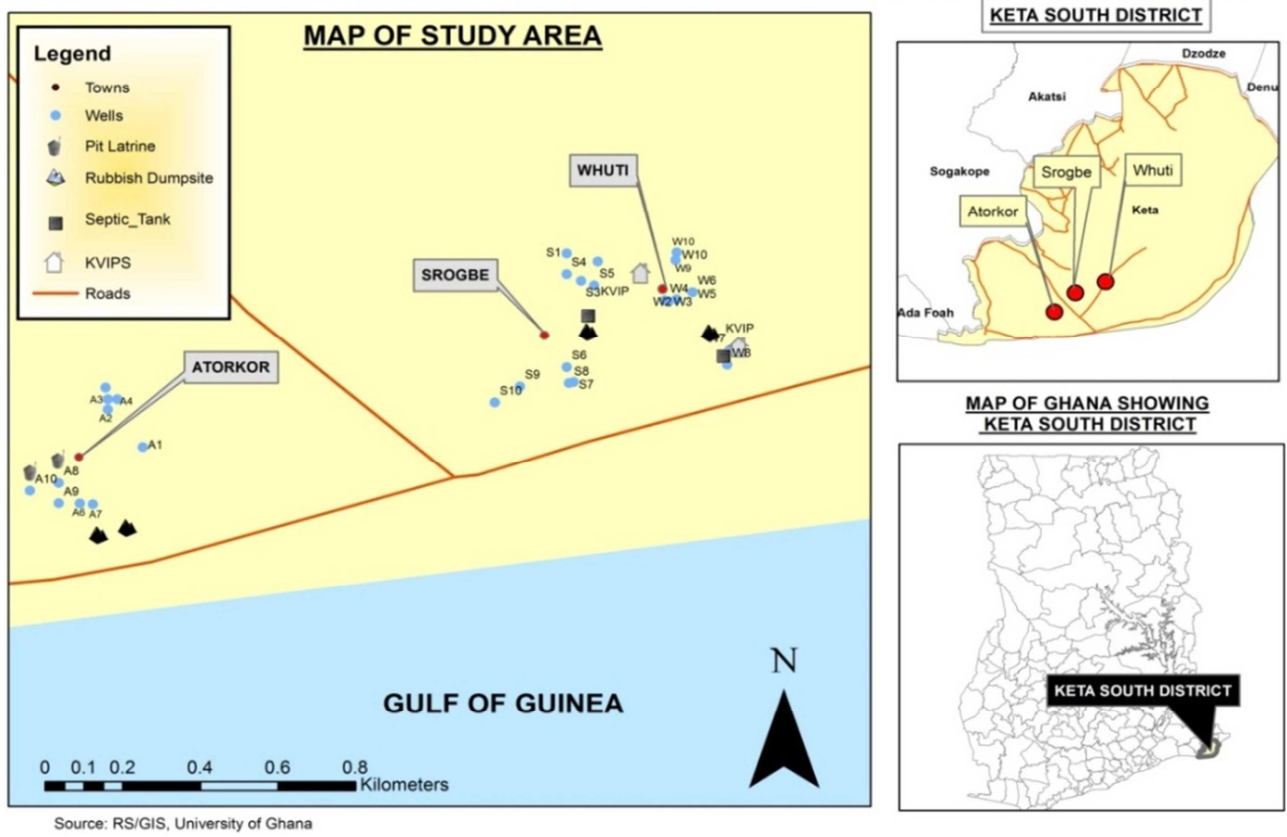

Figure 1. Map of study area and positions of select hand dug wells.

\subsection{Study Design and Sampling}

A reconnaissance survey was undertaken and the communities were selected, based on similarity in geological conditions, and distances from pollution sources. The communities selected for this study were Atorkor, Srogbe and these villages located in the Keta district. They are located in the low lying areas of the district and most members of households depended on hand dug wells in the homes, which 
had relative distances from sanitary facilities and the coastal environment hence appropriate for the objectives of this study. Garmin etrex GPS (accuracy $3 \mathrm{~m}$ ) was used to georeference sample positions selected hand dug wells; ten sampling hand dug wells were selected from each community during the sampling period.

\subsection{Data Collection}

Ten groundwater samples were obtained from the three communities based on simple balloting.

All the water samples were taken from the bottom of the wells, which had average depths between $20 \mathrm{~m}-30 \mathrm{~m}$. All water samples were collected in sterile 0.5 liter bottles. All samples were stored and transported in a cool box kept below $4^{\circ} \mathrm{C}$. Analyses were performed as soon as the samples were carried to the laboratory. All samples were stored in a cool box kept below $4^{\circ} \mathrm{C}$ and analyses performed as soon as the samples were transported to the laboratory.

\subsection{Laboratory Procedures}

Physico-chemical water quality parameters of samples were determined at the field and in the laboratory, under established standard methods as prescribed by APHA (1995), WHO (1987) and UNESCO/WHO (1978).

Groundwater samples were analyzed for Temperature, $\mathrm{pH}$, Conductivity, Total dissolved solids were measured in situ on the field using the HANNA Temp/pH/EC/TDS meter (Model HI 99301).

Groundwater turbidity was measured using the $2100 \mathrm{P}$ Turbidimeter.

$$
\text { Hardness }=2.47(\mathrm{Ca}, \mathrm{mg} / \mathrm{L})+4.118(\mathrm{Mg}, \mathrm{mg} / \mathrm{L})
$$

Calcium and Magnesium concentrations were measured using the Ion Chromatographer; Nitrate, Phosphate, Sulphate HACH DR/2000 Spectrophotometer all in the laboratory.

\subsection{Statistical Analysis}

Data was coded and entered into Statistical Package for Social Science (SPSS) version 20.0 for analysis. Mean \pm Standard deviation was obtained for all variables. Differences between dry and wet seasons were compared using independent sample t-test. Analysis of variance (ANOVA) was used to determine difference in chemical properties of the wells between the three towns. Analysis of variance (ANOVA) was used to test for differences in season and chemical properties of well water within and between the different communities and Turkey's b test was used to show where the difference were significant at a p-value $<0.05$. Spearman rank correlation was used to determine the relation between the different chemical properties of well water at $\mathrm{p}<0.05$ and $\mathrm{p}<0.01$.

\section{Results and Discussion}

Table 1. Chemical properties of the wells by season.

\begin{tabular}{llll}
\hline Characteristics & Season & Difference (Dry-Wet) \\
\cline { 2 - 4 } & Dry (Mean \pm SE) & Wet (Mean \pm SE) & (Mean \pm SE) \\
\hline $\mathrm{pH}$ & $7.24 \pm 0.09$ & $7.18 \pm 0.08$ & $0.06 \pm 0.13$ \\
Conductivity $(\mathrm{mg} / \mathrm{L})$ & $2612.30 \pm 626.60$ & $3747.17 \pm 568.89$ & $-1134.87 \pm 846.33$ \\
TDS $(\mathrm{mg} / \mathrm{L})$ & $1291.22 \pm 308.58$ & $2096.47 \pm 348.71$ & $-805.25 \pm 465.64$ \\
Turbidity $(\mathrm{mg} / \mathrm{L})$ & $1.91 \pm 0.22$ & $2.61 \pm 0.31$ & $-0.69 \pm 0.38$ \\
Nitrate $(\mathrm{mg} / \mathrm{L})$ & $2.57 \pm 0.22$ & $2.05 \pm 0.16$ & $0.52 \pm 0.27$ \\
Phosphate $(\mathrm{mg} / \mathrm{L})$ & $1.76 \pm 0.36$ & $0.82 \pm 0.09$ & $0.94 \pm 0.37$ \\
Sulphates $(\mathrm{mg} / \mathrm{L})$ & $70.80 \pm 9.98$ & $71.97 \pm 9.93$ & $-1.17 \pm 14.08$ \\
Calcium $(\mathrm{mg} / \mathrm{L})$ & $59.11 \pm 8.060$ & $57.13 \pm 7.74$ & $1.97 \pm 11.17$ \\
Magnesium $(\mathrm{mg} / \mathrm{L})$ & $84.48 \pm 20.46$ & $82.17 \pm 18.05$ & 0.07 \\
\hline
\end{tabular}

*Significant at $\mathrm{p}<0.05$

Table 2. Differences in chemical properties of the wells by Communities.

\begin{tabular}{|c|c|c|c|c|c|c|}
\hline \multirow[b]{2}{*}{ Characteristics } & \multicolumn{3}{|l|}{ Dry season } & \multicolumn{3}{|l|}{ Wet season } \\
\hline & $\begin{array}{l}\text { Atorkor } \\
(\text { Mean } \pm \text { SD) }\end{array}$ & $\begin{array}{l}\text { Srongbe } \\
(\text { Mean } \pm \text { SD) }\end{array}$ & $\begin{array}{l}\text { Whuti } \\
(\text { Mean } \pm \text { SD) }\end{array}$ & $\begin{array}{l}\text { Atorkor } \\
(\text { Mean } \pm \text { SD) }\end{array}$ & $\begin{array}{l}\text { Srongbe } \\
(\text { Mean } \pm \text { SD) }\end{array}$ & $\begin{array}{l}\text { Whuti } \\
(\text { Mean } \pm \text { SD) }\end{array}$ \\
\hline $\mathrm{pH}$ & $6.90 \pm 0.51^{\mathrm{a}}$ & $7.41 \pm 0.39^{b}$ & $7.42 \pm 0.47^{b}$ & $7.16 \pm 0.73^{A}$ & $7.33 \pm 0.14^{\mathrm{A}}$ & $7.06 \pm 0.40^{\mathrm{A}}$ \\
\hline Conductivity (mg/L) & $612.40 \pm 298.05^{\mathrm{a}}$ & $4560.90 \pm 4453.37^{b}$ & $2663.60 \pm 3060.53^{\mathrm{a}, \mathrm{b}}$ & $4679.90 \pm 3493.91^{\mathrm{A}}$ & $3891.90 \pm 3226.15^{A}$ & $2669.70 \pm 2527.80^{A}$ \\
\hline TDS (mg/L) & $306.45 \pm 149.01^{\mathrm{a}}$ & $2280.45 \pm 2226.68^{b}$ & $1286.75 \pm 1435.12^{\mathrm{a}, \mathrm{b}}$ & $2339.90 \pm 1747.02^{\mathrm{A}}$ & $1719.50 \pm 1551.56^{\mathrm{A}}$ & $2230.00 \pm 2460.04^{A}$ \\
\hline Turbidity (mg/L) & $2.25 \pm 1.80^{\mathrm{a}}$ & $1.67 \pm 0.83^{\mathrm{a}}$ & $1.82 \pm 0.96^{\mathrm{a}}$ & $2.16 \pm 1.73^{\mathrm{A}}$ & $2.24 \pm 0.99^{\mathrm{A}}$ & $3.43 \pm 1.99^{\mathrm{A}}$ \\
\hline Nitrate $(\mathrm{mg} / \mathrm{L})$ & $2.35 \pm 1.25^{\mathrm{a}}$ & $2.55 \pm 0.66^{\mathrm{a}}$ & $2.81 \pm 1.41^{\mathrm{a}}$ & $2.08 \pm 1.22^{\mathrm{A}}$ & $1.74 \pm 0.66^{\mathrm{A}}$ & $2.32 \pm 0.62^{\mathrm{A}}$ \\
\hline Phosphate (mg/L) & $1.20 \pm 0.49^{\mathrm{a}}$ & $2.43 \pm 3.31^{\mathrm{a}}$ & $1.65 \pm 0.59^{\mathrm{a}}$ & $1.01 \pm 0.37^{\mathrm{A}}$ & $0.87 \pm 0.60^{\mathrm{A}}$ & $0.57 \pm 0.31^{\mathrm{A}}$ \\
\hline Sulphates (mg/L) & $36.30 \pm 10.29^{\mathrm{a}}$ & $95.00 \pm 67.90^{b}$ & $81.10 \pm 53.15^{\mathrm{a}, \mathrm{b}}$ & $36.80 \pm 13.79^{\mathrm{A}}$ & $103.00 \pm 59.11^{\mathrm{B}}$ & $76.10 \pm 58.20^{\mathrm{A}, \mathrm{B}}$ \\
\hline Calcium (mg/L) & $54.77 \pm 37.20^{\mathrm{a}}$ & $69.05 \pm 55.33^{a}$ & $53.51 \pm 40.86^{\mathrm{a}}$ & $54.13 \pm 37.48^{A}$ & $66.48 \pm 52.99^{\mathrm{A}}$ & $50.79 \pm 37.90^{\mathrm{A}}$ \\
\hline Magnesium (mg/L) & $92.63 \pm 53.54^{\mathrm{a}}$ & $66.01 \pm 57.35^{\mathrm{a}}$ & $94.80 \pm 183.71 \mathrm{a}^{\mathrm{a}}$ & $89.86 \pm 49.20^{\mathrm{A}}$ & $63.20 \pm 56.23^{A}$ & $88.44 \pm 169.49^{A}$ \\
\hline
\end{tabular}

*Letters ranging from A-C and a-c within a row with the same superscript indicates no significant difference but those with different superscript shows significant differences 
Association which establish important relationships was conducted to know the relationship between chemical properties and season. There was a statistically significant association between Nitrate and season with $\mathrm{p}$ value of 0.04 . Also, there was an association between Phosphate and seasons with $p$ value of 0.01 . However, there was no significant association between calcium and the magnesium in the two seasons.

Differences in chemical properties of the wells were determined in all three communities between wet and dry seasons. There was a statistical significance between sulphate $(\mathrm{mg} / \mathrm{L})$ in the wet season in all three communities with a mean $( \pm \mathrm{SD})$ of $36.80 \pm 13.79,103.00 \pm 59.11$ and $76.10 \pm$ 58.20 respectively. However, there was no statistical significance difference in $\mathrm{pH}$ likewise conductivity $(\mathrm{mg} / \mathrm{L})$ in the wet season with respect to the communities. Turbidity and Calcium were also not different in the wet seasons in the three communities.

In the dry season, there was a statistical difference in $\mathrm{pH}$ in Atorkor, Srongbe and Whuti with mean $( \pm$ SD) of $6.90 \pm 0.51$, $7.41 \pm 0.39$ and $7.42 \pm 0.47$ respectively. More so, there was a statistical difference in conductivity in the dry season in the three communities. TDS $(\mathrm{mg} / \mathrm{L})$ was also shows differences in the dry season with a mean $( \pm \mathrm{SD})$ of $306.45 \pm 149.01$ in Atorkor, $2280.45 \pm 2226.68$ in Srongbe and $1286.75 \pm$ 1435.12 in Whuti. Differences in sulphate $(\mathrm{mg} / \mathrm{L})$ was recognized to be significant in the wet seasons in all tree communities. Their mean (SD) were $36.30 \pm 10.29,95.00 \pm$ 67.90 and $81.10 \pm 53.15$ respectively.

Table 3. Correlation matrix of the chemical properties of the wells and distance from source of pollution.

\begin{tabular}{|c|c|c|c|c|c|c|c|c|c|}
\hline \multirow{2}{*}{ Properties } & \multicolumn{9}{|c|}{ Dry season } \\
\hline & Distance & pH & conductivity & TDS & Turbidity & Nitrate & Phosphate & Sulphate & Calcium \\
\hline $\mathrm{pH}$ & $0.365^{*}$ & & & & & & & & \\
\hline Conductivity (mg/L) & $0.468 \#$ & 0.207 & & & & & & & \\
\hline TDS (mg/L) & $0.479 \#$ & 0.218 & $0.999 \#$ & & & & & & \\
\hline Turbidity (mg/L) & -0.155 & -0.174 & -0.253 & -0.252 & & & & & \\
\hline Nitrate $(\mathrm{mg} / \mathrm{L})$ & 0.167 & 0.111 & -0.193 & -0.181 & -0.124 & & & & \\
\hline Phosphate $(\mathrm{mg} / \mathrm{L})$ & -0.162 & 0.108 & -0.124 & -0.123 & 0.256 & 0.154 & & & \\
\hline Sulphate $(\mathrm{mg} / \mathrm{L})$ & $0.376^{*}$ & $0.442 *$ & $0.649 \#$ & $0.641 \#$ & -0.054 & 0.119 & -0.068 & & \\
\hline Calcium (mg/L) & $0.398^{*}$ & 0.220 & 0.244 & 0.257 & 0.004 & 0.008 & -0.226 & 0.096 & \\
\hline Magnesium (mg/L) & $\begin{array}{l}0.763 \# \\
\text { Wet seasor }\end{array}$ & 0.218 & 0.153 & 0.161 & -0.044 & -0.002 & -0.128 & 0.107 & $0.485 \#$ \\
\hline $\mathrm{pH}$ & $0.405^{*}$ & & & & & & & & \\
\hline Conductivity (mg/L) & $0.557 \#$ & $0.479 \#$ & & & & & & & \\
\hline $\mathrm{TDS}(\mathrm{mg} / \mathrm{L})$ & $0.439^{*}$ & 0.291 & $0.788 \#$ & & & & & & \\
\hline Turbidity (mg/L) & 0.221 & 0.296 & 0.127 & 0.146 & & & & & \\
\hline Nitrate $(\mathrm{mg} / \mathrm{L})$ & 0.039 & 0.086 & 0.055 & 0.157 & -0.033 & & & & \\
\hline Phosphate (mg/L) & -0.238 & 0.055 & -0.107 & -0.181 & -0.201 & 0.247 & & & \\
\hline Sulphate $(\mathrm{mg} / \mathrm{L})$ & $0.419^{*}$ & 0.204 & $0.501 \#$ & $0.401 *$ & 0.176 & -0.148 & $-0.472 \#$ & & \\
\hline Calcium (mg/L) & $0.383^{*}$ & 0.305 & $0.548 \#$ & $0.423^{*}$ & 0.122 & 0.004 & -0.307 & $0.461^{*}$ & \\
\hline Magnesium (mg/L) & $0.758 \#$ & 0.165 & 0.316 & 0.193 & 0.124 & -0.100 & -0.310 & $0.377 *$ & $0.463 \#$ \\
\hline
\end{tabular}

*significant at $\mathrm{p}<0.05$; \#significant at $\mathrm{p}<0.01$

Table 3 shows a correlation matrix of the chemical properties of the wells and distance from source of pollution. In the dry season, there was a weak but significant correlation between $\mathrm{pH}$ and distance $(\mathrm{r}=0.365)$. The correlation between conductivity and distance was moderate and significant at $\mathrm{p}<0.01(0.468)$.

There was also a moderate and significant correlation between TDS and distance $(\mathrm{r}=0.479)$ but a very strong and significant correlation between TDS and conductivity $(\mathrm{r}=0.999)$ at $\mathrm{p}<0.01$. There was a weak but significant correlation between Calcium and distance $(\mathrm{r}=0.398)$ and $\mathrm{a}$ strong correlation between Magnesium and distance $(\mathrm{r}=0.763)$.

In the wet season, $\mathrm{pH}$ and distance showed a moderate and significant correlation. There were moderate and significant correlations between conductivity and distance $(\mathrm{r}=0.557)$ as well as $\mathrm{pH}(\mathrm{r}=0.479)$. TDS and distance showed a significant moderate correlation $(\mathrm{r}=0.439)$, whiles TDS and conductivity showed a strong and significant correlation $(\mathrm{r}=0.788)$. In addition, there was significant correlations between Sulphate and Distance $(\mathrm{r}=0.419)$, conductivity $(\mathrm{r}=0.501)$ and TDS $(\mathrm{r}=0.401)$. However, there was a negative but significant correlation between Sulphate and Phosphate.

\subsection{Groundwater Resource Use and Sanitation}

Ground water is the major source of water for drinking, agricultural, and industrial desires. Low-income communities that do not have access to clean drinking water have become increasingly reliant on untreated well and borehole water for drinking, domestic activities and farm irrigation (Kouame et. al 2012). The selected communities significantly depend on hand dug wells for their domestic activities which include activities such as washing, cooking and drinking. The high dependence on the hand dug wells is as a result of the lack of accessibility to alternative sources of water supply in the communities. These local people had either little or no knowledge about possible contamination sources into hand dug wells. Hence they do not ensure strict sanitary measures around wellheads. Most chemicals from water sources are of 
health concern in humans as a result of exposure through drinking (Douagui et al., 2012).

\subsection{Physico-chemical Quality of Groundwater}

The characteristics of water that may affect its acceptability due to aesthetic considerations such as color and taste; these sometimes produce toxic reactions, unexpected physiological responses of laxative effect (Mor $e t$ al., 2006). The results obtained were validated using World Health Organization. The results show variations in temperature values recorded for the hand dug wells; global climatic conditions resulting in fluctuating temperatures, as well as differences in the depth of the hand dug well may account for differences in temperature values. There is no guideline value for temperature as it mainly depends on the ambient conditions. Temperature affects the state and level of other parameters including conductivity and bacteriological activity is also affected by temperature (Hoko, 2008). The $\mathrm{pH}$ values of the water sampled from all three communities fell within the WHO guidelines of drinking water quality which is 6.5-8.5. At low $\mathrm{pH}$, water is corrosive and could cause wear of equipment of metallic pump of abstraction material (Schafer et al., 2012), and the corrosive effects of water with low $\mathrm{pH}$ can be harmful to the health if used for drinking purpose or cooking.

With the exception of one hand dug well in Srogbe, which was sampled in March, all the communities recorded high turbidity values; the reason for the high ionic content of these wells is due to mineralization, by periodic sea water intrusion. Turbid waters demand relatively higher dosages of disinfectants if disinfection becomes necessary and it is often the only treatment method for groundwater (Hoko, 2008). It also promotes the microbial proliferation, thus affecting negatively the microbiological quality of water.

Its importance lies in its measure of salinity, which generally affects the taste and therefore, impacts on the user acceptance of the water. WHO limit for conductivity in drinking water should not exceed $500 \mu \mathrm{Sm}^{-1}$ (WHO, 2004). High conductivity values were recorded in the study communities and these high values may be due to the periodic salt water intrusion into hand dug wells, thus accounting for the presence of dissolved ions in water. This also explains the high conductivity values recorded in hand dug wells located in close proximity to the sea in all three communities.

Calcium and magnesium were measured to determine the aesthetic quality of groundwater which accounts for hardness in water, leading to bad taste and coloration of cooking utensils (Schafer et al., 2010). Hardness is caused by a variety of dissolved polyvalent metallic ions predominantly calcium and magnesium cations (WHO, 2004). In all the three communities, calcium levels in hand dug wells exceeded the WHO guideline for drinking water, irrespective of their proximity to pollution sources. High calcium concentration above $10 \mathrm{mg} / \mathrm{l}$ could lead to the development of kidney stones in sensitive people (Belizi, 1999). Magnesium concentrations in sampled hand dug wells showed that, magnesium levels were high exceeding WHO guidelines for drinking water quality. High levels of $\mathrm{Mg}$ in water may lead to bitter taste and may cause a laxative effect to consumers (Galvin, 1996).

This phenomenon of high levels of hardness results in scales developing in water heaters, well pumps, boilers and cooking utensils, and it would require a lot more soap for washing clothes as observed by Rao (2005).

Nitrate concentration in Atorkor, Srogbe and Whuti were all within WHO guideline for drinking water. This does not rule out the fact that with time, nitrate pollution could become a major contamination issue in this area because of the expanding agricultural activities. Nitrates has high retention time in the soil Aydin (2006), and can persist in ground water for decades thus, accumulating to high levels as more nitrogen is applied to the land surface every year through farming activities (Nolan et al., 1998). High nitrate levels in drinking water leads to infant methaemoglobinaemia, and at higher levels, livestock poisoning could occur.

With the exception of one hand dug well in Whuti, relatively high levels of phosphate in groundwater sample exceeded the WHO guideline value of $<0.3$ were recorded in all three communities. Proximity of a hand dug well (which recorded one of the highest phosphate concentrations) to a toilet facility and a farm is a possible source of the high phosphate levels; excessive algal growth on the walls of the hand dug well was an indicator of the high phosphate levels recorded in this particular well. Excess nutrients in water can trigger unpleasant ecological effects such as algal bloom, and the point sources of pollution such as sewage treatment sites are easy to identify (Whelan et al., 2008). Sulphate determines aesthetic value of water, because high Sulphate affects the taste in drinking water (Schafer et al., 2010). Sulphate concentrations in the sampled hand dug wells in the three communities' fell within WHO guideline limits of drinking water quality. As water moves through soil and rock formations that contain sulfate minerals, some of the sulfate dissolves into the groundwater.

\section{Conclusions}

Some physico-chemical parameters did not show statistically significant differences in concentration irrespective of their distance from the possible contamination sources, apart from temperature and phosphate.

There was also a highly significant correlation in between conductivity and TDS in all the three communities.

Mean values of hardness measured in all three communities were exceeded WHO limits of $500 \mathrm{mg} / \mathrm{L}$ for water quality.

There was relatively high levels of phosphate in groundwater sample exceeding the WHO guideline value of $<0.3$ were recorded in all three communities.

\section{Recommendations}

Alternative sources of water such as rainwater harvesting 
techniques could be implemented to augment the groundwater resources.

Wells identified to have nutrient (phosphate) concentration well water could be used for irrigation purposes.

Households could consider siting wells uphill in the communities in order to reduce rates of possible infiltration into groundwater.

And the distance between a well and a polluting source should not less than $50 \mathrm{~mm}$.

Research into bio fouling and educating the local people on effective management regime would help in preventing the problem of bio fouling.

From the findings of this study, a further research could be undertaken to into microbiological contamination of groundwater abstraction containers in households to establish the source of coliform in groundwater.

Acknowledgement

This research was funded by DANIDA, to support research among postgraduate students in African Universities, under the project BSCU (Building Stronger Universities).

\section{References}

[1] Aydin, A. (2006). The Microbiological and physic-chemical Quality of Groundwater in Thrace, Turkey. Journal of Environmental Studies, 16, 377-383.

[2] Banoeng-Yakubu, B. K., Akabzaa, M., Hotor. V. \& Danso S. K. (2006). The application of electrical resistivity techniques in the delineation of seawater-freshwater in the Keta Basin, Ghana. In Y. Xu, B. Usher (Eds.), Groundwater Pollution in Africa. (pp. 193-202). Taylor \& Francis/Balkema. 353 pp.

[3] Basavaraddi, S. B., Kousar, H., \& Puttaiah, E. T. (2012). Seasonal Variation of groundwater quality and its suitability for drinking in and around Tiptur Town, Tumkur District, Karnataka, India: A WQI Approach. Int. J. Comput. Eng. Res, 2, 562-567.

[4] Bellizzi, V., DeNicola, L., Minutolo, R., Russo, D., Cianciaruso, B., Andreucci, M. \& Andreucci, V. (1999). Effects of water hardness on urinary risk factors for kidney stones in patients with idiopathic nephrolithiasis. Nephron, 81 (Suppl. 1), 66-70.

[5] Douagui, A. G., Kouame, I. K., Koffi, K., Goula, A. T. B., Dibi, B., Gone, D. L., ... \& Savane, I. (2012). Assessment of the bacteriological quality and nitrate pollution risk of Quaternary groundwater in the southern part of Abidjan District (Côte d'Ivoire). Journal of Hydro-environment Research, 6 (3), 227-238.

[6] Finlayson, C. M., Gordon C., Ntiamoah-Baidu, Y., Tumbulto, J., \& Storrs, M. (2000). The Hydrobiology of Keta and Songor lagoons: Implications for wetland management in Ghana. Supervising Scientist Report 152, Supervising Scientist, Darwin.
[7] Galvin, M. (1996). Occurrence of metals in waters: an overview. Water S. A., 22 (1), 7-18.

[8] Graham, J. P., \& Polizzotto, M. L. (2013). Pit latrines and their impacts on groundwater quality: a systematic review. Environmental health perspectives, 121.

[9] Helstrup, T., Jorgensen, N. O \& Banoeng-Yakubo, B., (2007). Investigation of hydrochemical characteristics of groundwater from the Cretaceous-Eocene limestone in southern Ghana and southern Togo using hierarchical cluster analysis. Journal of Hydrogeology, 15, 977-989.

[10] Hoko, (2008). An assessment of quality of water from boreholes in Bindura District, Zimbabwe. Physics and Chemistry of the Earth, 33, 824-828.

[11] Kouame, I. K., Douagui, A. G., Koffi, K., Gouala A. T. B., Dibi, B., Gone, D. L., Coulibaly, K., Seka, A. M., Koussi, A. K., Mangwa, J. M. O., \& Savane, I. (2012). Assessment of the bacteriological quality and nitrate pollution risk of Quaternary groundwater in the southern part of Abidjan District. Journal of Hydro-environment Research 6, 227-238.

[12] Mor, S., Ravindra, K., Dahiya, R. P., \& Chandra, A. (2006). Leachate characterization and assessment of groundwater pollution near municipal solid waste landfill site. Environmental monitoring and assessment, 118(1-3), 435-456.

[13] Moyo, N. A. G. (2013). An analysis of the chemical and microbiological quality of ground water from boreholes and shallow wells in Zimbabwe. Physics and Chemistry of the Earth, Parts $A / B / C, 66,27-32$.

[14] Nolan, B. T., Ruddy, B. C., Hitt, K. J. \& Helsel, D. R. (1998). A National Look at Nitrate Contamination of Ground Water. Water Conditioning and Purification, vol 39 (12), pp 76-79.

[15] Palamuleni, L., \& Akoth, M. (2015). Physico-Chemical and Microbial Analysis of Selected Borehole Water in Mahikeng, South Africa. International journal of environmental research and public health, 12 (8), 8619-8630.

[16] Rao, (2005). Seasonal variation of groundwater quality in a part of Guntur District, Andhra Pradesh, India. Environmental Geology, 49: 413-429.

[17] Schafer, A. I., Rossiter, H. M. A., Owusu, P. A., Awuah E. \& MacDonald, A. M. (2010). Chemical drinking water quality in Ghana: Water cost and scope for advanced Treatment. Science of the Total Environment, 408, 2378-2386.

[18] Whelan (2008) Groundwater Phosphate, A driver for eutrophication? Retrieved from www.projectwet.org

[19] WHO (2004). Guidelines for Drinking Water. Volume 1, Recommendations, ( $3^{\text {rd }}$ Edition). World Health Organization, Geneva.

[20] Yidana, S. M., Banoeng-Yakubo, B., Akabzaa, T. M. (2010). Analysis of groundwater quality using multivariate and spatial analyses in the Keta basin, Ghana. Journal of African Earth Science, 58, 220-234. 